\title{
Benefits and challenges of doing task-based language teaching in Indonesia: Teachers' perception
}

\section{Teguh Hadi Saputro ${ }^{1}$, Aninda Nidhommil Hima ${ }^{2, *}$, Rafika Rabba Farah ${ }^{3}$}

Program Studi Pendidikan Bahasa Inggris, Fakultas Keguruan dan Ilmu Pendidikan, Universitas Muhammadiyah Malang, J1. Raya Tlogomas No 246 Malang, Indonesia

Iteguhhadisaputro@umm.ac.id, aninda@umm.ac.id², rafikafarah@gmail.com³

*Corresponding author: aninda@umm.ac.id

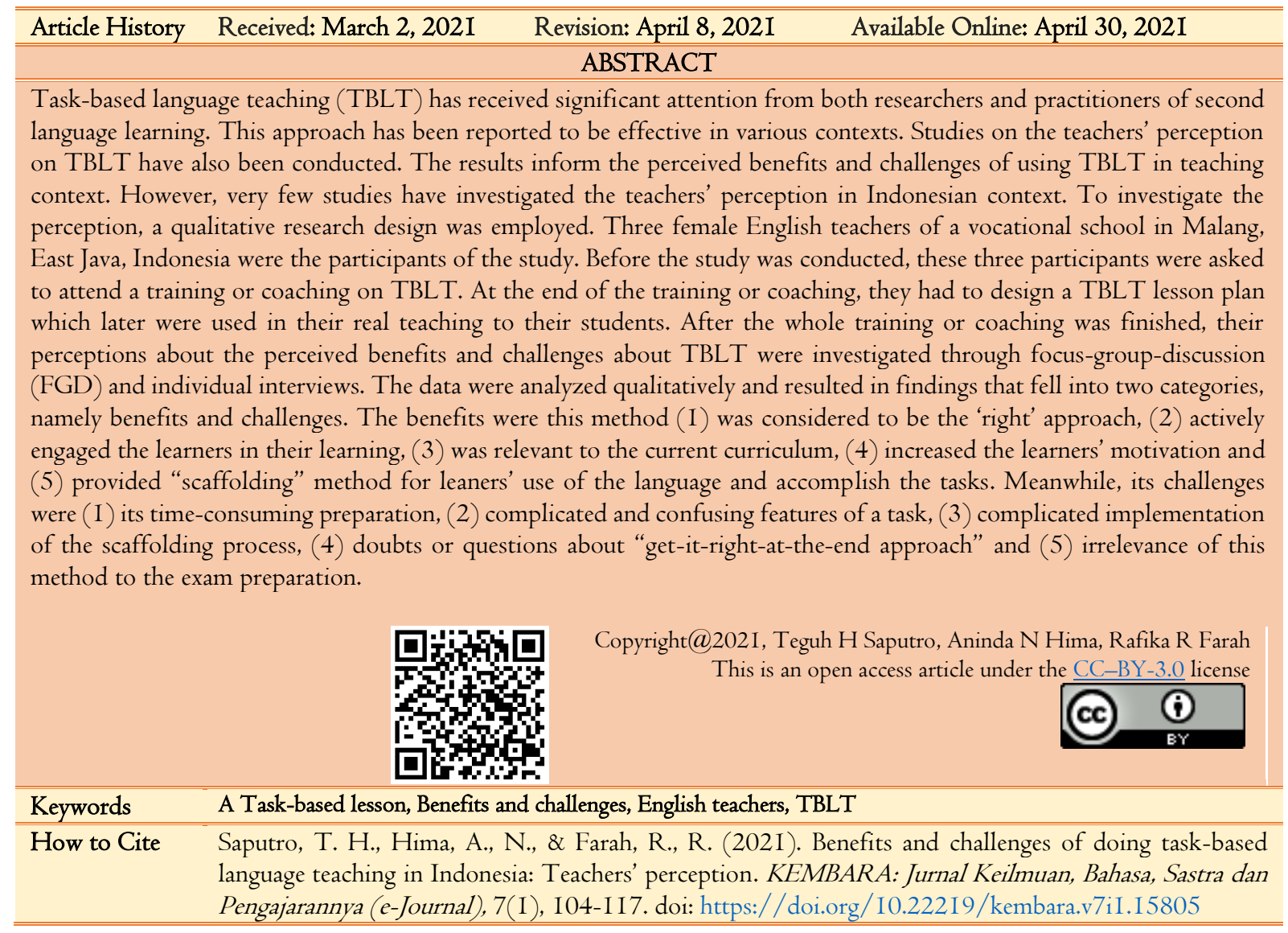

\section{INTRODUCTION}

Task-based language teaching (TBLT) has received significant attention from both researchers and practitioners of second language learning (Douglas \& Kim, 20I4; Grant, 20I7; Tan, 2016). As an approach that is developed further from communicative language teaching (CLT), TBLT also emphasizes the importance of learners being taught communicatively. However, the difference of them lies on how TBLT defines what a task really is and how a task sequence is designed and developed (East, 20I2; Ellis, 2003; Nunan, 2004). The effectiveness of TBLT has also been reported in many contexts (Gilabert et al., 2016; Grant, 20I7; Norris, 2016). The strength of TBLT in promoting natural learning in the classroom context seem to be the main factor of its effectiveness in enhancing L2 learners' skill (Ellis, 2003, 2009, 2015; Shintani, 20I I).

Despite the effectiveness of TBLT reported in a number of studies, the issues of designing and developing a task-based lesson is still significant from teachers' perspective. Some teachers feel that designing a task-based lesson is very complex (Carless, 2009; Sheen, 2006; Shintani, 20II). The complexity here comprises (I) understanding the nature a task (Ellis, 2003; Willis \& Willis, 2007), (2) 
designing the sequence that integrate a good scaffolding technique (Révész \& Gurzynski-Weiss, 2016), (3) a distinguished way in teaching forms (Douglas \& Kim, 20I4; Tan, 2016) and (4) doing assessment (Douglas \& Kim, 20I4; Willis \& Willis, 2007). With regard to those items of complexity, some teachers are not confident and reluctant to employ TBLT in their teaching.

In addition to the challenges, many studies has also reported the perceived benefits of TBLT (Douglas \& Kim, 2014; Grant, 2017; Tan, 2016). Most of the benefits derive from what and how teachers perceive a task-based lesson implemented in the real class. TBLT way of providing a natural learning environment for L2 learners is deemed to be the prominent factor that contributes to the teachers' perceived effectiveness (Andon \& Eckerth, 2009; Van den Branden, 2016). Further, the fact that TBLT refers all its practice based on the second language acquisition (SLA) theories and research is also TBLT's strong point to be considered in L2 teaching (Ellis, 2003). Those factors are acknowledged by teachers. They can also find that learners can learn to use the language more as they are exposed to meaning-focused tasks and increase their motivation on learning it day by day (Pietri, 20I5).

Despite that it has been a number of studies exploring the perception of L2 teachers about TBLT, only few discussed it within Indonesia context. This is deemed necessary to explore the Indonesian context in relation to TBLT as the findings of the L2 teachers' perception in Indonesia about TBLT was still mostly about the strength or benefit of TBLT in theoretical context. This study offers not only the benefits, but also challenges of this method in a very specific context after the teachers have had some trainings about TBLT and try it out in their classroom. Therefore, this study aims at investigating the English teachers' perception, by exploring the perceived benefits and challenges, about designing, developing and implementing a task-based lesson in Indonesian context of English teaching and learning. This study contributes to the body of knowledge in the field of TBLT and, at the same time, explores the Indonesian teaching context. In addition, it is also expected that the study will provide an insightful information for teachers who might currently implement TBLT and even newly start the method.

\section{METHOD}

This study was carried out in qualitative design. The qualitative research design was employed to explore the perceived benefits and challenges of TBLT from teacher perspective. It was also important to point out that the design would give comprehensive understanding of this particular topic being investigated. A case study design was also the nature of the current study as it investigated a particular phenomenon in a particular institution that involved three research participants. Focus group discussion (FGD) and interviews were the technique used in the study to explore and elicit the qualitative data about the perceived benefits and challenges. The FGD and interviews were conducted after a series of training or coaching on Task-Based Language Teaching (TBLT).

The study was carried out on January 2020. It involved three English teachers in a private vocational school at Malang, East Java, Indonesia. The teachers were all female and aged between 40-50 years old. They had relevant academic background to be English teachers. They earned their bachelor degree in English Education from private universities in Indonesia. They had been teaching English in the vocational school for averagely I8 years. Related to TBLT, they were firstly introduced and exposed to TBLT on the TBLT training and coaching which was a part of the study.

The vocational school in the study was located in Malang, East Java, Indonesia. This private vocational school had six vocational fields to offer, namely (I) Machinery Engineering, (2) Light Vehicle Engineering, (3) Electrical Engineering, (4) Motorcycle Engineering, (5) Computer and Network Engineering and (6) Nursing Assistance. The curriculum employed in the school was The Revised Version of 2013 Curriculum (the recent national curriculum). In this curriculum, English was taught in 5 teaching hours (250 minutes) in a week. Based on the preliminary observation, English classes were 
conducted somehow traditionally in a way that they are exam-driven and teacher-centered although the national curriculum recommended a more communicative outcome based and learner-centered English classes.

Prior to carrying out the research, a TBLT training and coaching had been conducted as the implementation of a project of community service to a school. This project required the project team to provide community service to a school that had situations or problems that could be "overcome" or at least "treated" by harnessing the expertise of the project team. TBLT training and coaching was chosen as the way to overcome or treat the English teachers' problems of learners' low achievement and motivation in learning English.

The training or coaching was divided into two phases, i.e. the workshop and implementation (practice) phase. The workshop phase aimed at giving the teachers basic knowledge and skill in designing task-based lesson. In this phase, the teachers had to follow I6-hour workshop which comprised four sessions. The sessions were (I) workshop on general understanding of TBLT, (2) workshop on how to determine the TBLT-oriented communicative outcome from the teaching goals, (3) workshop on how to select the materials, develop the task sequence and design the assessment in TBLT and (4) workshop and mentoring on lesson plan design and development. Each session was conducted in four hours. Meanwhile, the implementation phase required the teachers to use the lesson plan they made in the previous phase in their real classroom. In this regard, each teacher did only a I50-minute session to teach their students using TBLT. Further, only three classes were used in the implementation phase. They were (I) Computer and Network Engineering class (2) Nursing Assistance class and (3) Motorcycle Engineering class. The justification of the class selection was that the three classes were deemed prioritized classes by the teachers as the selection were mostly given to the teachers to make. It was mainly based on the aspects of the availability, the teachers' convenience and the students' level. All the classroom activities were video-taped so as to provide ways for the teachers to recall what happened in the classroom in the research process.

As the current study attempted to investigate the perceived benefits and challenges of the implementation of TBLT, qualitative approach was taken to provide more detailed and deeper findings on the subject matter. The data were collected by focus group discussion (FGD) and interview. The FGD was conducted in the first stage in order to get the common or general perception about the subject matter. In this regard, three participants attended the FGD and discussed the benefits and challenges of TBLT implementing in their teaching. The whole discussion in the FGD was audio-taped. After the FGD, the individual interviews with each teacher were conducted for in-depth investigation of what had been found in the FGD. Also, in case there might be anything that the teachers could not express during the FGD sessions. The interviews were also audio-taped.

In term of the data analysis, the data were analyzed iteratively. As stated earlier, the FGD was conducted on the first stage. Therefore, the recording of the FGD session was scripted. The transcription was then analyzed qualitatively to elicit the emerging themes and supports for each of them. Next, the analysis results were used to construct the questions for interviews. After the interviews were conducted, the recordings were also scripted. The analysis of the transcription of the interviews were used not only to triangulate the results of the FGD, but also elicit any possible emerging theme. At the end, the findings were based on the triangulated results of both FGD and interview transcription analysis.

\section{RESULT AND DISCUSSION}

Result

The results of focus group discussion (FGD) and interviews are divided into the benefits and challenges of doing task-based language teaching (TBLT).

\section{Benefits}

I. TBLT was perceived as a 'right' teaching method or approach. 
The teachers considered TBLT as a good and 'right' teaching method as compared to their current way of teaching English to their students. They defined 'right' as this method or approach had provided better learning opportunities for their students. TBLT was perceived to be able to involve students in meaning-focused activities in which feedback could be obtained not only from teachers, but also from their classmates. Also, the students had more time to use the language during accomplishing the tasks. Previously, in their Pesentation-Practice-Production (PPP) way of teaching, the teachers felt that they talked most of the time while students were mostly still less active in the class. Most of the time, in PPP class, they needed to always lead the students and 'police-monitored' them all the time. This did not occur during the implementation of TBLT in their class. The students were mostly monitored by the tasks and classmates as they had to finish it while the teachers could play more roles other than just a police (monitoring), such as an assistant, a source person, a consultant, and other more meaningful roles in accomplishing the students' tasks.

"I feel like my students learned more during their class when we used TBLT. They discussed with each other, talked about certain difficult words and found ways to deal with any difficulties. It was obvious that they enjoyed the class more than the way I had always used, the PPP." (A, FGD)

"I could do more interesting roles than just monitor them all the time, scold those who did not do the activities. You know, it could be so tensed. That day (TBLT practice), I found myself somehow merged with them in finishing their tasks. So relaxing and fun." (B, Interview)

"It's been a while I don't see them so active in the class. Previously, I would always remind them to be active, like it is good to be active for their future. But, you know, it is a hard thing to do as a teacher. So, I guess TBLT made it." (C, FGD)

\section{TBLT actively engaged students in learning English.}

The features of the tasks and the design of its task sequence encouraged students to actively participate in the teaching and learning process. Seeing the way the tasks and task sequence were commonly developed, the teachers had the impression that they were rigorously designed and developed in a sense that they would engage the students in such a way that the students would learn a lot of things. In this sense, the teachers some had been convinced about the effectiveness of TBLT in engaging the students in their class even before the implementation stage was carried out. In addition, after the implementation stage, the teachers had acknowledge the capability of the tasks and task sequence in promoting an engaging class where the students were an active learners as they had to accomplish the tasks.

"It is really a very thoughtful way to design and develop the tasks. I myself might not be really confident that I can do it. TBLT promotes more active learning that for me will engage the students effectively." (B, Interview)

"I'm not surprised that the students will be actively engaged. The design of the tasks made it possible for the students to actively participate in the learning." (A, Interview)

3. TBLT was deemed relevant with the current curriculum in Indonesia.

The teachers posited that TBLT main features and concepts were in line with 2013 Curriculum's main features and concepts. 2013 Curriculum was Indonesia national curriculum for elementary and secondary school levels. This curriculum emphasized the learners' outcome, learner-centered learning, and learners' systematic plan which were wrapped into a concept of 'scientific method.' In this regard, the teachers believed that the six features of a task that comprised work plan, focus on meaning, real-world 
process, four language skills, cognitive process and communicative outcome are to certain extent relevant to the concept of "scientific method."

"I strongly feel that TBLT might be what our 2013 Curriculum demands us to do. TBLT is so much about learner-centered teaching. You know like the students should be the ones using the language for certain purpose of teaching." (C, FGD)

"I do agree. Also, in TBLT we have workplan right? It is just the same as I learned it in the national teacher training that to do scientific approach in teaching and learning process, the students should be allowed and encouraged to develop a plan to achieve the goal." ( $A, F G D$ )

"I would not personally tell you that they are the same, but I could see the core features are somewhat the same. The way the students are assessed seems to be similar too. TBLT and 2013 Curriculum might have the same principles. (A, Interview)

4. TBLT could increase students' motivation in learning English.

The teachers' opinions about the students' motivation that seemed to be promoted by TBLT were mostly based on the implementation stage and the students' opinion after the implementation stage. The teachers acknowledged that TBLT could increase their students' motivation from their students' enthusiasm in the class. They noticed that the students were engaged and enjoyed the class. Despite the fact that the engagement and the enjoyment might not be sufficient to conclude the dynamic nature of motivation, they both served as positive signs of the students' motivation. In addition, most of the teachers reported the students' positive attitudes towards the implementation of TBLT. The students themselves told the teachers that they found the English class was more fun and more interesting than their previous ones.

"I would say the engagement and how the students enjoyed the class are the fact that I could say they are highly motivated." ( $A, F G D)$

"Two of us (the teachers) met them on the next day after the TBLT implementation stage. They said that they were excited and they really enjoyed the English class they had." (B, FGD)

5. TBLT's scaffolding helps students to "use" the language and "accomplish" the tasks.

The design a task sequence was known to have the scaffolding aspect that helped the students to accomplish the target tasks. The teachers were full aware of how the scaffolding concept was employed in the design of a task sequence. The scaffolding aimed to give students sufficient input necessary to prepare and equip the students to go through the task sequence. The teachers, in this case, believed that this scaffolding aspect is one of the major factors that made TBLT could elevate the learning value. They also noticed that the scaffolding design in TBLT was quite challenging to make as it would not allow explicit form teaching as the form of the scaffold.

"I would tell that TBLT is quite different in a way it provides the scaffolding. I have to admit that it is not easy, but surely good for students." ( $A, F G D$ )

"Yeah, the scaffold does help the students to do task by task, very helpful, but as a teacher, I would say it is not easy, quite challenging. " ( $B, F G D)$

"The best part of TBLT for me is the scaffolding part, all the tasks should be well related and connected. It will surely help students to deal with the target task. It also means that it helps the students to learn more. However, I would say that it is challenging." (C, Interview) 


\section{Challenges}

I. TBLT was time-consuming in terms of the preparation

Most of the teachers showed their concerns on the time seemingly needed to prepare a task-based lesson. As compared to PPP, TBLT indeed required more time for the teachers to prepare the lesson. One teacher shared that a process of making a task sequence from the target task and build the facilitating tasks based on the scaffolding concept seemed to be challenging. Further, each task in the task sequence should meet the six criteria of a task in TBLT which made it even more challenging for the teachers. They also reported that their other works than teaching made them less confident that they had a lot of time to design a task-based lesson.

"I don't know, I mean TBLT is good and I think it's very suitable with my students. But, the preparation time to design a task-based lesson can be very long and challenging. Teachers here have a lot of things to do, like administration jobs that made things seem very hard." (C, Interview)

"The criteria of a task, I should think of them to make a good task. Also, how to sequence them without any explicit grammar or form teaching. I was just wondering how many weeks or even months I need to prepare everything." (A, Interview)

"My biggest concern is the preparation time. I guess it will be time-consuming as to design a taskbased lesson. PPP is way simpler in terms of the preparation." (B, FGD)

2. Understanding the features of a task was quite complicated and confusing

The six criteria of a task were perceived to be confusing and complicated by the teachers. During the FGD and interview, the teachers were repeatedly asked about how they understood the six features of a task. They mostly found them overwhelming in a way that they had to think of those six criteria when designing a task, not to mention that the concept of the criteria itself was still confusing for them. They mostly still had questions on some criteria, such as workplan, real-world process and communicative outcome. They could help comparing TBLT and PPP in terms of how easy PPP activity could be designed and developed.

"Well, the six criteria of the tasks themselves are not easy to understand. I mean, after you understand them, you need to be able to make one which is the most difficult one." (B, Interview)

"I am still having problem with the criteria of real-world process, workplan and communicative outcome. You know, they are easy to be defines but once I tried to make a task, I found myself struggling. And, talking to you helps a lot." (A, Interview)

"The criteria of workplan and communicative outcome are somehow confusing for me. I know that workplan is to give choice to the students and communicative outcome is to aim to learning outcome beyond the language (forms). But, I still cannot say them easy to be implemented." (C, Interview)

3. The scaffolding method was not easy to implement.

Rather similar, the scaffolding concept in TBLT was also deemed somewhat easy to define, but difficult to implement. The teachers were not used to define scaffolding as a "no explicit form teaching." They had used to think that the scaffold could be in the form of teaching forms before the students did the language practice. As the scaffold in TBLT should also be in the form of a task, most of the teachers found it challenging when it came to put it into the task sequence design.

"Another issue that is related to the issue of the six features of a task is the scaffolding which I think is superb, but also challenging. I need to think every task through so they could scaffold one to the next one. It is so challenging and somehow difficult. I think I need to learn more." (A, Interview) 
"I would say the scaffolding is really challenging for me. PPP again is simpler. It is easy to get it and use. Scaffolding in TBLT is also a task and a task should follow the six criterias." (C, Interview)

4. "Getting-right-in-the-end" remained a big question.

The fact that TBLT required the teachers to teach forms explicitly in the end of the task sequence was a new concept to the teachers. As stated earlier, the teachers previously had taught the forms to the students as the scaffold to the practice and production stage as commonly done in PPP approach. Thus, the teachers still doubted the effectiveness of the "getting-right-at-the-end" approach in TBLT although they had been informed the justification and benefits of this particular approach to the students' learning and acquisition.

"This teaching grammar or vocabulary in the end of the task sequence is somehow 50:50 to me. I mean, I have got the reasons of how this way can help the students to learn more, but you know part of me still considers it to be taught at the very beginning. But, I am not sure." (A, FGD)

"Yeah, I agree with her opinion. I think I need to try it more. I am afraid that the students might not be able to catch all the points to be taught in the explicit teaching when it is given at the end of the sequence." (B, FGD)

"This approach is justified, well justified. Students could notice their mistake and they could make sense of it. It is just me who probably is not ready yet to do the change." (C, FGD)

5. TBLT was not an approach to prepare students for an exam.

As the teachers in this school focused more on the national exam, they found that TBLT was not suitable with classes that were going to face the national exam. They argued that TBLT seemed to be good for the first and second grade students who were yet facing the exam, but the third grade ones should be taught using the conventional way to get them familiar with the test items in the exam. The conventional way here were either the PPP or mostly test-preparation teaching.

"For learning of how to communicate, TBLT is a perfect teaching approach. However, I am not sure that it can be good for the exam preparation. I need to focus on the test items and how the students should do the test." (C, FGD)

"I agree. I mean, it is very appropriate for the students in the first and second grade. They do not have to face the examination test yet. But, for the third grade ones, I have to use technique like PPP or maybe test preparation one to teach them." ( $A, F G D$ )

\section{Discussion}

Most of the literature on TBLT has suggested its benefits and effectiveness on the L2 learning. This current study revealed that that TBLT was perceived to be a 'right' teaching approach. This positive perception about TBLT has been well reported by quite a number of studies from various contexts (Andon \& Eckerth, 2009; Carless, 2004; Edwards \& Willis, 2005; Ellis, 2015; Van Gorp \& Van den Branden, 20I5). Most of them argue that TBLT is able to provide natural learning and, thus, create better learning opportunity and engaging learning atmosphere (Ellis, 2003; Nunan, 2004; Willis \& Willis, 2007). The natural learning was promoted as the design of a task-based lesson involves learners to a more meaning-focused activity to achieve a certain communicative outcome. This indicates that during the lesson, learners are engaged in meaningful tasks or activities without any explicit form teaching just as how people learn language in a natural way. Natural learning, in this case, has been claimed to offer more values in learning a second language (Ellis, 2003, 20I5; Li et al., 2016). Offering more values also means providing better learning opportunity. TBLT with its all features within the tasks and task sequences help 
the learners to pick up language in a way that the process is more implicit and thus allows possible more language to be learned other than what have been targeted by teachers (East, 20I4; Mcdonough, 20I5). In addition, the possible feedback given by peers and teachers during the meaning-focused activity should also be considered as the positive value for learning. As working through tasks in a task sequence, learners are likely to both give and receive feedback that might be in the form of the topic and/or form (Boston, 2008). This particular feedback is important for learners in terms of helping them to both mine and notice the language items during the process of accomplishing the tasks (Crabbe, 2007; Long, 2005; Nation \& Macalister, 20I0; Van den Branden, 2016).

In addition, the better learning opportunity promoted by TBLT is mostly to be in line with learners' motivation in learning English. As learned from the findings above, the teachers believed that during and after the implementation stage, the students were highly motivated. Although the arguments for the motivation were mainly based on the teachers' observation and students' positive response after the implementation stage, Dörnyei (2005) explains that they can serve as the pre indication of current state of the motivation. Meanwhile, empirically NamazianDost, Bohloulzadeh, \& Pazhakh (2017) and Pietri (2015) have each done an experimental study on the effectiveness of TBLT on their learners' motivation. Both reports that applying TBLT in the L2 classroom can increase learners' motivation. Some possible factors have been explained previously, that TBLT promotes more natural L2 learning that encourages learners' engagement. This engagement is commonly associated with high level of motivation. Further, as tasks in TBLT are carefully designed to facilitate the development of learners' cognitive skills (Ellis, 2003; García Mayo, 2015; Nunan, 2004), learners' success in accomplishing tasks in a task sequence is considerably a high chance. In this case, a sense of success can always be achieved by learners (Shehadeh \& Coombe, 2012; Van den Branden, 2016). Eventually, the sense of success leads to high level of motivation (Brown, 200I; Dörnyei, 2005).

With regard to facilitating the cognitive-based learning, a task-based lesson is designed and developed in a way that follows the scaffolding concept (Willis \& Willis, 2007). It means that former tasks scaffold later tasks so as to help learners to accomplish all tasks in a sequence. Most of L2 teaching approaches acknowledge the significance of scaffolding due to the fact that $\mathrm{L} 2$ learners should be provided with such necessary and relevant supports during their learning (Mirada, 2007; Nation, 2008; Nation \& Macalister, 2010). However, the difference that TBLT has in terms of providing the supports is that they cannot be in any form of explicit teaching, but communicative tasks. Again, it is relevant with the notion of natural learning. In this regards, learners are expected to mine the language and topic supports necessary to equip them to do the next tasks (Willis \& Willis, 2007). As the mining process is facilitated by meaningful tasks, teachers should be aware that their tasks should embed the language items and topic that learners need to mine. Also, the cognitive demands should be carefully implemented in designing a task sequence for most effective learning (Robinson, 200I). With all aspects being embedded in a task sequence, it is not surprising that the teachers in the current study felt that the concept of scaffolding in TBLT can assist their learners to use the language and accomplish the tasks.

Another point about the benefits of TBLT in the current study is the relevance of TBLT to current Indonesia national curriculum. Minister of Education and Culture No 160 of 2014 about the Implementation of 2006 Curriculum and 2013 Curriculum states and regulates the current Indonesia Curriculum, namely 2013 Curriculum (Rohim, 2015). This national curriculum employs a scientific approach which advocates the outcome-based, learner-centered, and cognitive-based learning. The approach falls into three practical teaching methods, namely inquiry-based learning, problem-based learning and project-based learning (Rohim, 2015). These three practical teaching methods have the same concept as TBLT as we can learn from East (2012), Ellis (2003), Nunan (2004) and Willis \& Willis (2007). Both TBLT and 2013 Curriculum are based on the outcome-based, learner-centered and cognitive based learning. Therefore, the perception of the teachers in the current study about the similarity and relevance of TBLT to the national curriculum is justified. In this regard, English teachers in Indonesia context should be able to implement TBLT in their classroom. 
From the above discussed benefits, some challenges claimed by the teachers in the study are also worth discussing. Preparation time is one of many challenges that the teachers have during designing and implementing a task-based lesson. This particular concern has also been reported in some relevant studies (Douglas \& Kim, 2014; Rubaiat, 2018; Widodo, 2006). For teachers that use Presentation-PracticeProduction (PPP) technique in designing their lessons, they are likely to find that designing a task-based lesson might cost their time a lot. Carless (2009) argues that designing a lesson in TBLT is indeed more complex than doing in PPP. As stated earlier, in doing TBLT, teachers should consider the features of a task, the scaffolding aspect that does not allow explicit teaching and cognitive demands. Meanwhile, PPP allows explicit form teaching that makes it easier for teachers to design a lesson. Moreover, learners' production is comparably easier to be controlled in PPP than in TBLT as a result of providing explicit teaching in the scaffolding process. Regardless the complexity of the TBLT over PPP, some studies have provided evidence that TBLT outperforms PPP in terms of the effectiveness in the classroom context (Sheen, 2006; Shintani, 20II). Therefore, although it is time-consuming for teachers to design a taskbased lesson, all the work will be paid off.

In addition to time preparation, the teachers' doubt on the TBLT's focus on forms which is given in the end of the task sequence has also been discussed in several literature. This placement of focus-onform activity raises the issue of both how the students get the scaffold learning and the students' awareness of their mistakes (Douglas \& Kim, 20I4; Hismanoglu \& Hismanoglu, 20II; Iveson, 20I5; Tan, 20I6). This doubt and question are still associated with teachers' use of PPP in their teaching. The explicit form teaching in the presentation stage of PPP is intended to provide the scaffold and model for learners to the next stages (practice and production). However, placing the explicit form teaching at the beginning can increase students' anxiety as this explicit teaching will direct learners' attention towards accuracy (Skehan, 1996). As accuracy is highly associated with what is correct and incorrect, most learners, particularly low-level ones, tend to hesitate or worry to produce the language. In other words, the scaffold or model given in the PPP might risk students' willingness to use the language. Nevertheless, as PPP has somehow shaped the belief of the teachers in the current study in how form should be given, it might take some time for them to apply TBLT in their class and do some reflection which might change their belief about teaching forms.

TBLT has also received concern about its effectiveness in preparing students for an exam from the perspective of teachers in the current study. This particular concern has been reported as a common issue in Asian context (Douglas \& Kim, 20I4; Sato, 2009). In most of Asian contexts, English teaching is still driven by a formal exam. Therefore, some teachers feel that it is necessary to prepare their students to be able to do English exam rather than to teach English for communication. Most of the exam is associated with grammar and/or vocabulary tests. However, Ellis (2009) puts this particular thought as one of the misconceptions about TBLT. TBLT can also be used to prepare students for exam. In practical, teachers can design focused tasks in their lesson facilitate the learning of language items needed in the exam. Although facilitating the learning of language items, focused tasks are still in the form of tasks with all the features that meet the requirement as a task in TBLT Ellis (2009). However, again this particular concern is understandable as traditionally teachers likely believe that explicit form teaching as in PPP is the only and effective way to prepare students for an exam (Widodo, 2006).

Overall, the discussion and the benefits and challenges has given somehow a clear picture of perceived effectiveness of TBLT training or coaching and its implementation. A one-time seminar, conference or workshop to provide teachers with TBLT coaching does not seem to sufficient to a certain expectation of real class implementation (Müller-Hartmann \& Schocker-von Ditfurth, 20I I; Van den Branden, 2006). Teacher's belief about their previous practice might already bound tightly to them (Borg, 2006). Therefore, a follow up of TBLT training or coaching, like regular discussion about TBLT and mentoring, is urgently needed to help teachers to put TBLT into the real practice. 


\section{CONCLUSION}

As the benefits and challenges of using TBLT in L2 classroom have been pointed out and discussed, it can be concluded that the teachers can clearly see TBLT's capability in providing better learning opportunity although there are still concerns on how to do it. In this case, it can also be learned that the teachers perceive TBLT as a good approach when they witness or experience the real practice of TBLT in the classroom, but they see a lot of concerns when they have to design and develop one. Therefore, there should be effort or further research to address the challenges or problems. No matter how effective TBLT can be, it depends on the teachers as they are the designer and developer of lesson in the class.

\section{ACKNOWLEDGEMENT}

This research was fully funded by 2018 Block Grant Program of Faculty of Teacher Training and Education, Universitas Muhammadiyah Malang.

\section{REFERENCES}

Andon, N., \& Eckerth, J. (2009). Chacun à son gout? Task-based L2 pedagogy from the teacher's point of view. International Journal of Applied Linguistics, I9(3), 286-310. https://doi.org/IO.IIII/j.I473-4I92.2009.00240.x

Borg, S. (2006). Teacher cognition and language education: Research and practice. Continuum.

Boston, J. S. (2008). Learner mining of pre-task and task input. ELT Journal, 62(I), 66-76. https://doi.org/I0.1093/elt/ccm079

Brown, H. D. (200I). Teaching by principles: An interactive approach to language pedagogy. Longman Inc.

Carless, D. (2004). Issues in teachers' reinterpretation of a task-based innovation in primary schools. TESOL Quarterly, 384I63(4), 639-662. https://doi.org/I0.2307/3588283

Carless, D. (2009). Revisiting TBLT and P-P-P. Asian Journal of English Language Teaching, I9, I62I63.

http://www.embase.com/search/results?subaction= ${ }_{\text {viewrecord\&from }}=$ export\&id=L3643258 4\%5Cnhttp://dx.doi.org/I0.I I9I/02692I6303pm7IIop\%5Cnhttp://sfx.metabib.ch/sfx_1 ocator?sid=EMBASE\&issn=02692163\&id=doi:I0.I I9I/0269216303 pm7I Iop\&atitle=Fro $\mathrm{m}+$ Hong + Kong\&stitle $=\mathrm{P}$

Crabbe, D. (2007). Learning opportunities: Adding learning value to tasks. ELT Journal, 6I(2), II7I25. https://doi.org/I0.1093/elt/ccm004

Dörnyei, Z. (2005). The psychology of the language learner: Individual differences in second language acquisition. Lawrence Erlbaum.

Douglas, S. R., \& Kim, M. (20I4). Task-based language teaching and English for academic purposes: An investigation into instructor perceptions and practice in the Canadian context. TESL Canada Journal, 3I(8), I-22. https://doi.org/I0.I8806/tesl.v3Ii0.I I84

East, M. (2012). Task-based language teaching from the teachers' perspective: Insights from New Zealand. John Benjamins.

East, Martin. (20I4). Encouraging innovation in a modern foreign language initial teacher education programme: What do beginning teachers make of task-based language teaching? Language Learning Journal, 42(3), 26I-274. https://doi.org/I0.1080/0957I736.2013.856455

Edwards, C., \& Willis, J. (2005). Teachers exploring tasks in English language teaching. Palgrave Macmillan.

Ellis, R. (2003). Task-based language learning and teaching. London: Oxford University Press.

Ellis, R. (2009). Task-based language teaching: Sorting out the misunderstandings. International Journal of Applied Linguistics, I9 3), 22I-246. https:/ / doi.org/IO.I I I /j.I473-4I92.2009.0023I.x

Ellis, R. (2015). Teachers evaluating tasks. In M. Bygate (Ed.), Domains and directions in the 
development of TBLT (pp. 248-270). John Benjamins.

García Mayo, M. del P. (2015). The interface between task-based language teaching and content-based instruction. System, 54, I-3. https://doi.org/I0.1016/j.system.2015.09.003

Gilabert, R., Manchón, R., \& Vasylets, O. (2016). Mode in theoretical and empirical TBLT research: Advancing research agendas. Annual Review of Applied Linguistics, 36. https://doi.org/IO.I017/S0267190515000II2

Grant, S. (2017). Implementing project-based language teaching in an Asian context: a university EAP writing course case study from Macau. Asian-Pacific Journal of Second and Foreign Language Education, 2(I), I-I4. https://doi.org/I0.II86/s40862-017-0027-x

Hismanoglu, M., \& Hismanoglu, S. (20II). Task-based language teaching: What every EFL teacher should do. Procedia-Social and Behavioral Sciences, I5, 46-52. https://doi.org/I0.IOI6/j.sbspro.2011.03.049

Iveson, J. (2015). Challenges of task-based language teaching in online and blended learning contexts. Proceedings of the 7th International Conference on Computer Supported Education, 277-282. https://doi.org/I0.5220/0005474802770282

Li, S., Ellis, R., \& Zhu, Y. (2016). Task-based versus task-supported language instruction: An experimental study. Annual Review of Applied Linguistics, 36. https://doi.org/I0.1017/S0267190515000069

Long, M. H. (2005). Second language needs analysis. Cambridge: Cambridge University Press.

Mcdonough, K. (20I5). Perceived benefits and challenges with the use of collaborative tasks in EFL contexts. In M. Bygate (Ed.), Domains and directions in the development of TBLT (pp. 225 245). John Benjamins.

Mirada, L. (2007). Language scaffolding in second language writing. The CATESOL Journal, I9(I), 7I-88.Retrived from http://www.catesoljournal.org/wpcontent/uploads/20I4/07/CJI9_liang.pdf

Müller-Hartmann, A., \& Schocker-von Ditfurth, M. (20I I). Task-supported language learning. Verlag Ferdinand Schöningh.

NamazianDost, I., Bohloulzadeh, G., \& Pazhakh, A. (2017). The effect of task-based language teaching on motivation and grammatical achievement of EFL Junior High School Students. Advances in Language and Literaty Studies, 8(2), 243. https://doi.org/I0.7575/aiac.alls.v.8n.2p.243

Nation, I. S. P. (2008). Teaching ESL/EFL reading and writing. Routledge: Sage.

Nation, I. S. P., \& Macalister, J. (2010). Language curriculum design. Routledge: Sage.

Norris, J. M. (2016). Current uses for task-based language assessment. Annual Review of Applied Linguistics, 36, 230-244. https://doi.org/I0.1017/S0267190516000027

Nunan, D. (2004). Task-based language teaching. Cambridge: Cambridge University Press.

Pietri, N. J. M. (2015). The effects of task-based learning on Thai students' skills and motivation. Asean Journal of Management \& Innovation, 3(4), 72-80. Retrived from file:///C:/Users/LENOVO/Downloads/I I580-asean-journal-of-management-innovationvol-2-no-I-january-june-20I5.pdf

Révész, A., \& Gurzynski-Weiss, L. (2016). Teachers' perspectives on second language task difficulty: insights from think-alouds and eye tracking. Annual Review of Applied Linguistics, 36. https://doi.org/I0.1017/S02671905I5000124

Robinson, P. (200I). Task complexity, cognitive resources, and syllabus design: A triadic framework for investigating task influences on SLA. In P. Robinson (Ed.), Cognition and second language instruction (pp. 287-318). Cambridge University Press.

Rohim, F. (2015). Materi pelatihan guru implementasi kurikulum 20I3. Kementrian Pendidikan dan Kebudayaan.

Rubaiat, S. (2018). The effectiveness of task based language teaching in improving ESL learners' leading and writing skills. BRAC University, Dhaka, Bangladesh. 
Sato, R. (2009). Suggestions for creating teaching approaches suitable to the Japanese EFL environment. The Language Teacher, 33(9), I I-I4.

Sheen, R. (2006). Focus on forms as a means of improving accurate oral production. In A. Housen \& M. Pierrad (Eds.), Investigations in instructed Language acquisition (pp. 270-310). Mouton de Gruyter.

Shehadeh, A., \& Coombe, C. (2012). Task-based language teaching in foreign language contexts. John Benjamins.

Shintani, N. (20II). Task-based language teaching versus traditional production-based instruction: Do they result in different classroom processes? University of Sydney Papers in TESOL, 6, 97-I20. https://doi.org/I834-47I2

Skehan, P. (1996). A Framework for the implementation of task-based instruction. Applied Linguistics, I7(I), 38-62. https:// doi.org/I0.I093/applin/I7.I.38

Tan, Z. (2016). Benefits and implementation challenges of task-based language teaching in the chinese efl context. International Journal for Innovation Education and Research, 4(3), I-8. Retrived from http://www.ijier.net/ijier/article/view/522

Van den Branden, K. (2006). Task-based language education: From theory to practice. Cambridge: Cambridge University Press.

Van den Branden, Kris. (2016). The role of teachers in task-based language education. Annual Review of Applied Linguistics, 36, I64-181. https:// doi.org/I0.1017/S0267190515000070

Van Gorp, K., \& Van den Branden, K. (2015). Teachers, pupils and tasks: The genesis of dynamic learning opportunities. System, 54, 28-39. https://doi.org/I0.1016/j.system.2015.04.018

Widodo, H. P. (2006). Approaches and procedures for teaching grammar. English Teaching: Practice and Critique, 5(I), I22-I4I. https:/ / doi.org/I0.I0I7/CBO978I I074I5324.004

Willis, D., \& Willis, J. (2007). Doing task-based teaching. Oxford: Oxford University Press. 